\title{
Coming out in a harsh environment: a new genus and species for a land flatworm (Platyhelminthes: Tricladida) occurring in a ferruginous cave from the Brazilian savanna
}

\author{
Ana M Leal-Zanchet ${ }^{\text {Corresp., }}{ }^{1}$, Alessandro Damasceno Marques ${ }^{1}$ \\ 1 Instituto de Pesquisas de Planárias, Universidade do Vale do Rio dos Sinos - UNISINOS, São Leopoldo, Rio Grande do Sul, Brazil \\ Corresponding Author: Ana M Leal-Zanchet \\ Email address: zanchet@unisinos.br
}

Faunal inventories in ferruginous caves from an area belonging to the Brazilian savanna (Cerrado phytophysiognomy), on the eastern margin of the Serra do Espinhaço Plateau, in southeastern Brazil, have revealed the occurrence of land flatworms. Herein, a flatworm sampled in such subterranean environment is described as a new genus and species of the Neotropical subfamily Geoplaninae, Difroehlichia elenae gen. nov., sp.nov. The new genus shows rare features within Geoplaninae, namely sub-cylindrical body, poorly developed sub-epidermal musculature and a narrow creeping sole. Some features, such as a small body and a broad sensory margin in the anterior region of the body, as well as the fact that the holotype showed signs of recent copula, may indicate an adaptation to the subterranean environment, probably representing a troglophile. Difroehlichia elenae is characterized by an almost homogeneous dark brown pigmentation over dorsal surface and body margins, a short cylindrical pharynx, and a tubular and unforked intrabulbar prostatic vesicle, among other features. The holotype shows a secondary male copulatory organ located immediately behind the primary one, both communicating with the female atrium and gonopore canal. Since the species seems to have low abundance and restricted distribution and its type-locality is affected by mining activities, major concern arises regarding its conservation. 
1 Coming out in a harsh environment: a new genus and species for a land flatworm

2 (Platyhelminthes: Tricladida) occurring in a ferruginous cave from the Brazilian savanna

4 Ana Leal-Zanchet ${ }^{1}$, Alessandro Damasceno Marques ${ }^{1}$

$6{ }^{1}$ Instituto de Pesquisas de Planárias, Universidade do Vale do Rio dos Sinos, São Leopoldo, Rio 7 Grande do Sul, Brazil

9 Corresponding author: Ana Leal-Zanchet (zanchet@unisinos)

\section{Abstract}

14 Faunal inventories in ferruginous caves from an area belonging to the Brazilian savanna 15 (Cerrado phytophysiognomy), on the eastern margin of the Serra do Espinhaço Plateau, in southeastern Brazil, have revealed the occurrence of land flatworms. Herein, a flatworm sampled

17 in such subterranean environment is described as a new genus and species of the Neotropical 18 subfamily Geoplaninae, Difroehlichia elenae gen. nov., sp.nov. The new genus shows rare 19 features within Geoplaninae, namely sub-cylindrical body, poorly developed sub-epidermal 20 musculature and a narrow creeping sole. Some features, such as a small body and a broad 21 sensory margin in the anterior region of the body, as well as the fact that the holotype showed 
22 signs of recent copula, may indicate an adaptation to the subterranean environment, probably 23 representing a troglophile. Difroehlichia elenae is characterized by an almost homogeneous dark

24 brown pigmentation over dorsal surface and body margins, a short cylindrical pharynx, and a 25 tubular and unforked intrabulbar prostatic vesicle, among other features. The holotype shows a 26 secondary male copulatory organ located immediately behind the primary one, both 27 communicating with the female atrium and gonopore canal. Since the species seems to have low 28 abundance and restricted distribution and its type-locality is affected by mining activities, major 29 concern arises regarding its conservation.

\section{Introduction}

Land flatworms belong to the cryptofauna, since they are photophobic and depend on the moisture of their microhabitat because they do not have water-saving adaptations (Kawaguti, 1932; Froehlich, 1955a; Winsor, Johns \& Yeates, 1998). Such characteristics compel them to remain hidden during the day in humid refuges, as for example the leaf litter and under stones or fallen logs (Antunes, Leal-Zanchet \& Fonseca, 2012). They are predators of other invertebrates (Froehlich, 1955a; Ogren, 1995; Prasniski \& Leal-Zanchet, 2009; Boll \& Leal-Zanchet, 2016, Cseh, Carbayo \& Froehlich, 2017). Land triclads have restricted locomotion capacity over long distances, so there are many endemic species (Sluys, 1995).

In the Neotropical region, there have been some faunal inventories on land triclads, especially in southern South America, most of them in areas of Atlantic Forest (Leal-Zanchet \& 42 Carbayo, 2000; Castro \& Leal-Zanchet, 2005; Antunes, Marques \& Leal-Zanchet, 2008; Leal43 Zanchet \& Baptista, 2009; Baptista, Oliveira \& Leal-Zanchet, 2010; Amaral et al., 2014; 44 Negrete, Colpo \& Brusa, 2014). Some specific environments, however, are almost unexplored, 
45 such as the hypogean habitats. More than 11,000 caves have been documented in Brazil, 46 representing about only $10 \%$ of the potential number of caves in the country (Auler et al., 2001).

47

Caves are relatively stable environments regarding thermal and moisture conditions (Barr, 1968; Rocha \& Galvani, 2011; Pellegrini \& Ferreira, 2012), thus favouring the occurrence of land planarians. However, their diversity in such environments is almost unknown. Their occurrence in subterranean habitats may be occasional, searching for a shelter, as was probably the case of a recently described species of Geoplaninae, Pasipha ferrariaphila Leal-Zanchet \& Marques, 2018. Some species may be adapted to the cave environment, completing their life cycle both in hypogean or epigean habitats (troglophiles) or inhabiting exclusively the cave (troglobites), using it for foraging and reproduction (Barr, 1968).

Recently, a faunal inventory in ferruginous caves from an area belonging to the Brazilian savanna (Cerrado phytophysiognomy), on the eastern margin of the Serra do Espinhaço Plateau, in southeastern Brazil, indicated the occurrence of land flatworms in such subterranean environments (Leal-Zanchet \& Marques, 2018). Herein we study another species of land flatworm occurring in the same region, which shows features that allow its assignment to the Neotropical subfamily Geoplaninae. However, it could not been assigned to any known genus, and thus, we provide the description of a new genus and species to accommodate this flatworm.

\section{Material and Methods}

A single flatworm was collected during the day by direct sampling in the entrance zone of a ferruginous cave (FSS-0081) in Conceição do Mato Dentro (1856'48.1" S, 43²4'27.6" W), at an altitude of $810 \mathrm{~m}$ a.s.1., in the state of Minas Gerais, southeastern Brazil (Fig. 1). The 
67 specimen was fixed in $70 \%$ ethyl alcohol during field work. The preserved specimen was

68 analysed regarding colour pattern, body shape and dimensions and then photographed under a 69 stereomicroscope. Methods described by Rossi et al. (2015) were used for histological 70 processing of the material and analysis of external and internal characters. The material was 71 sectioned at intervals of $6 \mu \mathrm{m}$ and stained with Goldner's Masson or Haematoxylin/Eosin.

The field work was conducted under a collection license granted by Instituto Brasileiro 73 do Meio Ambiente e dos Recursos Naturais Renováveis - IBAMA (permit number $74 \quad 02015.004286 / 2010-49)$.

Type-material is deposited in the Helminthological Collection of Museu de Zoologia da Universidade de São Paulo, São Paulo, state of São Paulo, Brazil (MZUSP). The electronic 77 version of this article in Portable Document Format (PDF) will represent a published work 78 according to the International Commission on Zoological Nomenclature (ICZN), and hence the 79 new names contained in the electronic version are effectively published under that Code from the 80 electronic edition alone. This published work and the nomenclatural acts it contains have been 81 registered in ZooBank, the online registration system for the ICZN. The ZooBank LSIDs (Life 82 Science Identifiers) can be resolved and the associated information viewed through any standard 83 web browser by appending the LSID to the prefix http://zoobank.org/. The LSID for this 84 publication is: urn:lsid:zoobank.org:pub:A6418F77-34C3-413B-81E9-54296A74F2F6. The 85 online version of this work is archived and available from the following digital repositories: 86 PeerJ, PubMed Central and CLOCKSS. 
89 cmc common muscle coat

90 cov common glandular ovovitelline duct

91 cs creeping sole

92 di dorsal insertion of pharynx

93 e eyes

94 fa female atrium

95 fc female canal

96 go gonoduct

$97 \quad \mathbf{i}$ intestine

98 lu pharyngeal lumen

99 med main ejaculatory duct

100 mma main male atrium

101 mo mouth

102 mpv main prostatic vesicle

103 n nerve plate

104 o ovary

105 oe oesophagus

106 om outer musculature of pharynx

107 ov ovovitelline duct 
108 pp pharyngeal pouch

109 sbm sub-intestinal transversal muscles

110 sd sperm duct

111 sed secondary ejaculatory duct

112 sg shell glands

113 sm sensory margin

114 sma secondary male atrium

115 snm sub-neural transversal muscles

116 spm supra-intestinal transversal mesenchymal muscles

117 spv secondary prostatic vesicle

$118 \mathbf{t}$ testes

$119 \mathbf{v}$ vitellaria

120 ve ventral epidermis

121 vi ventral insertion of pharynx

122 vm ventral cutaneous musculature

123

124

125

Taxonomic description

126

Family Geoplanidae Stimpson, 1857 
Difroehlichia Leal-Zanchet \& Marques, gen. nov.

129

130

Type-species: Difroehlichia elenae sp. nov. Monotypic.

131

132

Genus diagnosis: Geoplaninae with small and slender body, sub-cylindrical in cross-section,

133

134

135

136

137 138 141 absent.

142

143

144

145

146

147

\section{Remarks}

with parallel margins; eyes mono- and trilobate, arranged along the body margins, absent on the very anterior tip; sensory margin broad; sensory pits in an irregular row on anterior body third, without contouring the tip; creeping sole narrow, less than half of body width; sub-epidermal musculature poorly developed; sub-epidermal and mesenchymal musculatures without cephalic specializations; longitudinal mesenchymal muscles absent; pharynx cylindrical; prostatic vesicle intrabulbar; male atrium short with eversible penis; ascending portion of ovovitelline ducts lateral to female atrium, joining each other dorsally to female canal or atrium; female canal dorsally flexed; female atrium obliquely disposed; adenodactyls or musculo-secretory papillae

The occurrence of dorsal testes and sub-epidermal longitudinal muscles arranged in bundles conform to the subfamily Geoplaninae, which currently has 24 genera (Carbayo et al., 2013). The new genus, however, shows poorly developed sub-epidermal musculature and a narrow creeping sole, which are rare features within Geoplaninae (Ogren \& Kawakatsu, 1990). 
149 Xerapoa has such a narrow creeping sole, being even narrower, with a width corresponding to 150 one-third of body width (Froehlich, 1955b; Ogren \& Kawakatsu, 1990), whereas the creeping 151 sole shows a width less than half of body width in Difroehlichia. In addition, Xerapoa shows 152 sensory pits opening at the tip of small papillae, main nervous system two-chord shaped, eyes 153 monolobate, ovaries close to the pharynx, ovovitelline ducts joining behind the female atrium 154 and a horizontal female canal (Froehlich, 1955b; Carbayo et al., 2013). Thus, the new genus can 155 be easily differentiated from Xerapoa by having sensory pits opening through a broad sensory 156 margin, a broad nervous plate, eyes mono- and trilobate, ovaries close to the anterior tip, 157 ovovitelline ducts joining dorsally to female canal or atrium and female canal dorsally flexed.

Etymology

160 The new genus honours the researchers Dr. Claudio Froehlich and the late Dr. Eudóxia 161 Froehlich, who developed an extensive and renowned study on land triclads. Gender: feminine. Difroehlichia elenae Leal-Zanchet \& Marques, sp. nov.

Type material. Holotype MZUSP PL2142: leg. Carste Ciência e Ambiente, 23 November 2016, 167 Conceição do Mato Dentro (1856'48.1" S, 43²4'27.6" W; altitude 810 m a.s.1.), state of Minas 168 Gerais (MG), Brazil - anterior tip: transverse sections on 6 slides; anterior region at the level of 169 the ovaries: sagittal sections on 5 slides; pre-pharyngeal region: transverse sections on 10 slides; 
170 pharynx: sagittal sections on 5 slides; copulatory apparatus: sagittal sections on 6 slides;

171 posterior region: sagittal sections on 4 slides.

172

173 Diagnosis

174 Difroehlichia elenae is characterized by an almost homogeneous dark brown pigmentation over 175 dorsal surface and body margins; pharynx cylindrical; prostatic vesicle tubular, unforked and 176 vertically disposed with two portions: a proximal, narrow ventral portion and a distal, globose 177 dorsal portion; ejaculatory duct short; male atrium globose occupied by a large circular fold; 178 male and female atria separated by a constriction; female atrium with folded walls and ample

179 lumen, tapering to communicate with the gonopore canal; length of female atrium about 2/3 of 180 male atrial length.

181

182 Etymology

183 The new species pays homage to a friend, the late Dr. Elena Diehl, who contributed to the 184 knowledge of the ecology of ants and termites in southern Brazil.

185

186 Type-locality: Conceição do Mato Dentro, state of Minas Gerais (MG), Brazil.

187

188 Description

189 External features 
Aspect of living specimen unknown. Body elongate with parallel margins, sub191 cylindrical; anterior and posterior tips rounded (Fig. 2). Length of $13.5 \mathrm{~mm}$, maximum width of $1921.5 \mathrm{~mm}$, and maximum height of about $0.8 \mathrm{~mm}$. In relation to anterior tip, mouth at $63 \%$ of body 193 length and gonopore at $78 \%$ of body length. the stereomicroscope, the light brown ground colour is apparent on the anterior tip and on the 196 median dorsal region. Creeping sole grayish, bordered by dark brown lateral parts of body. Whitish sensorial margin visible in the anterior body half (Fig. 2). pigment. Close to the anterior tip, eyes monolobate, with pigment cups of about $8 \mu \mathrm{m}$ in 201 diameter. Behind the tip, eyes become trilobate with larger pigment cups (about 15-30 $\mu \mathrm{m}$ in 202 diameter). The eyes become sparser towards the posterior tip.

Sensory organs, epidermis and body musculatures.

Anterior tip

Body elliptical in cross section just after the tip. Epidermis low $(3 \mu \mathrm{m})$ with few and sparsely distributed rhabditogen glands and few cyanophil glands with amorphous secretion. On anterior tip, openings from erythrophil glands absent. 
212 Sensory margin ventromarginally arranged and wide, occupying between $15 \%$ and $28 \%$

213 of body width on either side of body, with low, ciliated epithelium (Figs 3A, C), receiving

214 cyanophil glands with amorphous secretion. Sensory pits, as simple invaginations $(15-30 \mu \mathrm{m}$

215 deep), occur in one irregular row on either side of body in approximately the anterior third of

216 body, without contouring the tip. Behind the tip, sensory margin gradually becomes narrower

217 and receives openings from erythrophil glands with finely granular secretion, usually 3-4 gland

218 necks opening close to each other.

219 Cutaneous musculature thicker than that in pre-pharyngeal region, especially considering

220 its relation to body height, gradually diminishing in thickness towards anterior tip. Mesenchymal

221 musculature, slightly thicker in cephalic region than in pre-pharyngeal region, composed of 222 oblique fibres with various orientations, and three transverse layers: supra-intestinal, sub223 intestinal and subneural (Figs 3A-C); thickness gradually diminishes towards anterior tip.

225 Pre-pharyngeal region

226

Creeping sole (Figs 3D-F) with erythrophil, tall epithelium (twice taller than the rest of 227 the epidermis), showing an irregular height and densely arranged, long cilia. Its width 228 corresponds to between $40 \%$ and $50 \%$ of body width. Three gland types discharge through dorsal epidermis and body margins, as well as in the lateral portions of the ventral surface: rhabditogen cells with xanthophil secretion with relatively short rhammites (about $10 \mu \mathrm{m}$ long), cyanophil glands with amorphous secretion and sparse erythrophil glands with finely granular secretion.

232 Sparser rhabditogen cells with smaller rhabdites open through creeping sole. Glandular margin 233 absent (Fig. 3E). 
longitudinal layer thin and with small bundles (Figs 3E-F). Ratio of thickness of cutaneous

237 (about 8-12 $\mu \mathrm{m}$ ) at sagittal plane, similar to the epidermal height, excepting on creeping sole.

238 Cutaneous musculature almost twice thicker than epidermis on body margins (about $18 \mu \mathrm{m}$ ).

Mesenchymal musculature (Figs 3D-F) poorly developed, mainly composed of two

layers: (1) supra-intestinal transverse (about 2-3 fibres thick) and sub-intestinal transverse (about

$2413-4$ fibres thick). In addition, there are oblique and dorso-ventral fibres.

\section{Pharynx}

Pharynx cylindrical and short, nearly $4 \%$ of body length, occupying almost all length of 245 pharyngeal pouch (Fig. 4A). Pharyngeal dorsal insertion slightly posteriorly shifted, but still located in anterior third of pharyngeal pouch. Mouth in median third of pharyngeal pouch. Oesophagus short (Fig. 4A); oesophagus: pharynx ratio $12 \%$.

Pharynx and pharyngeal lumen lined with ciliated, cuboidal epithelium with insunk nuclei. Outer pharyngeal musculature comprised of thin subepithelial layer of longitudinal muscles, followed by a thicker layer of circular fibres. Inner pharyngeal musculature comprises a thick subepithelial layer of circular fibres, followed by a thinner layer of longitudinal fibres. Outer and inner musculatures have a maximum thickness of about $15 \mu \mathrm{m}$, gradually becoming thinner towards pharyngeal tip. Oesophagus lined with ciliated, cuboidal to columnar epithelium, with a few insunk nuclei, and coated with a thin muscle layer (about $10 \mu \mathrm{m}$ ) comprised of circular fibres interposed with longitudinal fibres. 


\section{Reproductive organs}

258

259

260

261

262

263

264

265

266

267

268

269

270

27

272

273

274 275

276

277 27 279

Testes in one irregular row on either side of body, located between intestinal branches (Fig. 3D). Testes begin posteriorly to ovaries, about $4 \mathrm{~mm}$ from anterior tip (30\% of body length), and extend slightly posterior to pharynx. Sperm ducts lateral to ovovitelline ducts, forming spermiducal vesicles posteriorly to pharynx. Laterally to penis bulb, sperm ducts ascend, enter the muscle coat and open terminally into the proximal portion of the prostatic vesicle. Intrabulbar prostatic vesicle tubular, unforked and vertically disposed (Figs 5, 6B). This vesicle shows two portions: proximal portion narrower and ventral; distal portion globose and dorsal (Figs 5, 6A-B). Ejaculatory duct short and narrow, arising from posterior region of prostatic vesicle and opening into the proximal portion of male atrium (Fig. 6C), dorsally displaced. Penis of eversible type. Male atrium short and globose with irregular contour and a large circular fold (Figs 5, 6A). Distal region of male atrium communicates with female atrium and gonopore canal through a constriction (Figs 5, 6A). Dorsolaterally to the gonoduct, a secondary male copulatory organ occurs (Figs 5, 6A, D-E), being displaced to the right and communicating with the distal portion of the female atrium and the gonoduct. It contains a smaller circular fold than that of the primary male atrium, receiving entally the opening of a short ejaculatory duct and a tubular, almost horizontally disposed prostatic vesicle, without anatomical differentiation between proximal and distal portions (Figs 6D-E). A single, incompletely developed sperm duct opens into the most proximal portion of this prostatic vesicle.

Epithelial lining of main and secondary prostatic vesicles ciliated and columnar, with irregular height, receiving finely granular weakly stained, erythrophil, probably mixed secretion (erythrophil core and a chromophobic peripheral part). In addition, distal portion of main and secondary prostatic vesicles receives coarse granular erythrophil secretion. Muscularis of main 
280 and secondary prostatic vesicle thick (about 6-12 $\mu \mathrm{m}$ thick), constituted of interwoven 281 longitudinal, circular and oblique fibres (Fig. 6C). Main and secondary ejaculatory ducts lined 282 with cuboidal to columnar epithelium, with irregular height and showing sparse cilia. Few glands 283 with amorphous, cyanophil secretion open into these ducts. Muscle coat of ejaculatory ducts thin 284 (about $3 \mu \mathrm{m}$ ), comprised of circular and longitudinal fibres. Main and secondary male atria lined 285 with non-ciliated epithelium, showing microvilli and receiving finely granular, erythrophil or 286 mixed secretion from glands with subepithelial cell bodies. Dorsal wall and proximal region of 287 main and secondary male atria, including the circular fold, lined by columnar epithelium, with 288 cells united to each other by their basal halves, whereas their apical cell halves are free, giving 289 corrugated appearance to epithelium (Fig. 6C). Ventral wall and distal region of main and 290 secondary male atria lined with cuboidal to flat epithelium. Their muscularis comprised of 291 circular fibres followed by longitudinal fibres, thicker proximally $(15-20 \mu \mathrm{m})$ than distally $(3-5$ $292 \mu \mathrm{m})$. Thick muscle fibres, radial disposed, cross the dorsal wall of both main and secondary male 293 atria.

Vitelline follicles, situated between intestinal branches, well-developed (Figs 3D-F, 4B).

295 Ovaries globose, somewhat pear-shaped, measuring about $0.15 \mathrm{~mm}$ in both longitudinal and 296 transversal axes. They are situated dorsally to ventral nerve plate (Fig. 4B), about $3 \mathrm{~mm}$ from 297 anterior tip (22\% of body length). Ovovitelline ducts emerge from lateral walls of ovaries, 298 dorsally displaced (Fig. 4B), and run posteriorly immediately above ventral nerve plate. Distal 299 sections of ovovitelline ducts run postero-medially lateral to female atrium and unite dorsally to 300 female canal, forming a short common glandular ovovitelline duct (Figs 5, 7A). Proximal portion 301 of female atrium with an antero-dorsally directed female canal. Female atrium roughly ovoid, 
302 obliquely inclined, with folded walls and ample lumen, tapering to communicate with the 303 gonopore canal (Figs 5, 6A, 7A). Length of female atrium about $2 / 3$ of male atrial length.

Ovovitelline ducts and common ovovitelline duct lined with cuboidal to columnar, 305 ciliated epithelium and coated with intermingled circular and longitudinal muscle fibres (6-10

$306 \mu \mathrm{m}$ thick). Shell glands discharge their erythrophil, ovoid granules into the common ovovitelline 307 duct and into the posterior sections of the ovovitelline ducts (Figs 5, 7A). Female canal lined 308 with columnar, ciliated epithelium, receiving abundant strongly cyanophil, amorphous secretion 309 from cell bodies located posterior to the copulatory organs. Female atrium lined with columnar 310 to pseudostratified, ciliated epithelium $(10-30 \mu \mathrm{m})$, with stratified appearance in some places, 311 reaching up to $70 \mu \mathrm{m}$, thus irregular in height. Some ciliated lacunae occur in this epithelium 312 (Fig. 7A). Glands of female atrium of two types: with cyanophil, amorphous and with finely 313 granular, erythrophil secretions. Musculature of female canal and atrium poorly developed (10$31415 \mu \mathrm{m}$ thick), composed of intermingled longitudinal and circular fibres (Figs 5, 6D).

315 Common muscle coat (Figs 5, 6A, C-E), consisting of longitudinal, oblique and circular 316 fibres, poorly developed (15-50 $\mu \mathrm{m}$ thick), thicker around ental portion of male atrium, forming 317 penis bulb. Male and female atria with continuous muscle coat. Gonoduct large, almost straight 318 at the sagittal plane (Figs 5, 6A). Lining epithelium of gonoduct columnar, ciliated, receiving 319 openings of two types of glands, one producing a finely granular erythrophil and the other an 320 amorphous, slightly cyanophil secretion. Muscularis of gonopore canal $(10-15 \mu \mathrm{m})$ comprised of 321 subepithelial circular fibres and subjacent longitudinal fibres. 
field work (Fig. 2). This specimen shows parts of an arthropod in its intestine. Female atrium

326

327

328

329

330

331

332

333

334

335

336

337

338

339

340

34

342

343

344

345

contains sperm and erythrophil, coarse granular secretion in its lumen, some sperm mixed with a slightly stained, apocrine secretion, indicating recent copula. This apocrine secretion also occurs in the gonoduct.

\section{Ecology and distribution}

The type-locality of Difroehlichia elenae belongs to the Brazilian savanna (Fig. 8), in an area characterized by rocky outcrops with lateritic cover. The cave surroundings show an open vegetation composed of herbs, shrubs and trees, associated with ferruginous rocks, which is characteristic of rupestrian complexes (Rapini et al., 2008, Oliveira et al., 2018). The typelocality is located close to that of Pasipha ferrariaphila, in an area planned for mining activities (Leal-Zanchet \& Marques, 2018). The sampling place is a low ferruginous cave (maximal height of $1.8 \mathrm{~m}$ ), showing $6.3 \mathrm{~m}$ of horizontal projection and an area of $9 \mathrm{~m}^{2}$. It is composed of banded iron rocks (Fig. 8B) covered by a crushed lateritic cap with some quartzite fragments. The cave is located at the basis of a $4 \mathrm{~m}$ high vertical slope (Fig. 8A). The flatworm was sampled in the entrance zone, which corresponds to $60 \%$ of the cave area. Only two samplings were carried out in the area in June (dry season) and November 2016 (wet season), the single specimen of $D$. elenae being collected in the latter. Other invertebrates, such as spiders (Ctenidae and Sicariidae) and insects (Zelurus, Eidmanacris and larvae of Lampyridae), also occurred in the cave.

\section{Discussion}


347 the entire body length, as presented by epigean species. However, D. elenae shows a small body 348 and a broad sensory margin in the anterior half of the body. Such characteristics may indicate an 349 adaptation to the subterranean environment. Adaptive features, such as hypertrophy of sensory 350 organs and reduction of body pigmentation, as well as reduction or absence of eyes, are usually 351 found in troglobites (Barr, 1968). that this flatworm is using the cave environment for reproduction, probably representing a troglophile. Land flatworms usually show low dispersion ability and may have strict ecological requirements that limit their occurrence to specific habitats, some species being affected by the conservation state of the habitat (Carbayo, Leal-Zanchet \& Vieira, 2002; Baptista, Oliveira \& inventories and ecological surveys, many species of land planarians were represented by unique or few specimens (Castro \& Leal-Zanchet, 2005; Antunes, Marques \& Leal-Zanchet, 2008; LealZanchet \& Baptista, 2009; Baptista, Oliveira \& Leal-Zanchet, 2010; Amaral et al., 2014; Negrete, Colpo \& Brusa, 2014). Similarly, only a single specimen of D. elenae was sampled in the faunal survey in ferruginous caves in the eastern margin of the Serra do Espinhaço Plateau. Hence, it is difficult to draw firm conclusions concerning the adaptation of this species to the cave environment.

The holotype of $D$. elenae shows a secondary male copulatory organ immediately behind 366 the primary one. It probably is in an initial stage of development, since it receives the opening of 367 a single, poorly developed sperm duct. Its occurrence may be either an anomaly or a functional 368 adaptation, constituting a populational feature or even a specific or generic characteristic, the 
369 latter occurring, for example, in some earwigs (Kamimura, 2006). The finding of other

370 representatives of the species is also necessary to shed light on this question.

371 The area, where the cave is located, has been intensively sampled, but the species was

372 collected exclusively in its type-locality (A. Leal-Zanchet, unpublished data). Thus, the species

373 seems to have a restricted distribution and, considering the mining impacts in its type-locality, a

374 major concern for its conservation is raised.

375

376 Conclusions

377 The new genus described herein shows rare features within Geoplaninae, such as sub-cylindrical

378 body, poorly developed sub-epidermal musculature and a narrow creeping sole. The holotype of

379 the new species has a small body and a broad sensory margin in the anterior region of the body, 380 and showed signs of recent copula. Such features may indicate an adaptation to the subterranean 381 environment, but since the specimen shows a heavily pigmented body and eyes along almost the 382 entire body length, it probably should be interpreted as a troglophile. Considering that the type-

383 locality is affected by mining activities, and the species seems to have a low abundance and 384 restricted distribution, major concern arises regarding its conservation.

387 We acknowledge Carste Ciência e Ambiente for samplings and information about the type 388 locality, as well as for the map and photos of the sampling place. We thank G. Iturralde for the 389 photo in Fig. 2A and the laboratory technician L. Guterres for her help in section preparation. 
390 M.Sc. E. Benya is acknowledged for an English review of the text. Dr Marta Álvarez-Presas, Dr

391 Fernando Carbayo and Dr. Leigh Winsor are gratefully acknowledged for their constructive 392 comments in an early version of the manuscript.

393

394 References

395 Amaral SV, Hack IR, Iturralde GG, Leal-Zanchet AM. 2014. Land flatworms (Platyhelminthes:

396 Tricladida) in remnants of deciduous forest in the northeast region of southern Brazil. Biota

397 Neotropica 14:1-6. http://dx.doi.org/10.1590/S1676-06020140045

398 Antunes MC, Marques DIL, Leal-Zanchet AM. 2008. Composição das comunidades de planárias

399 terrestres (Platyhelminthes, Tricladida, Terricola) em duas áreas de floresta estacional

$400 \quad$ semidecidual do sul do Brasil. Neotropical Biology and Conservation 31:34-38.

401 Antunes MB, Leal-Zanchet AM, Fonseca CR. 2012. Habitat structure, soil properties, and food

402 availability do not predict terrestrial flatworms occurrence in Araucaria Forest sites.

403 Pedobiologia 55:25-31.

404 Auler A, Rubbioli E, Brandi R. 2001. As grandes cavernas do Brasil. Belo Horizonte: Grupo

405 Bambuí de Pesquisas Espeleológicas.

406 Baptista VA, Oliveira SM, Leal-Zanchet AM. 2010. Inventário de planárias terrestres

407 (Platyhelminthes, Tricladida) em remanescente de Floresta Estacional Decidual do Sul do

408 Brasil. Biota Neotropica 10:247-252.

409 Barr TC. 1968. Cave ecology and the evolution of troglobites. In: Dobzhansky T, Hecht MK,

410 Steere WC, Eds. Evolutionary biology. Boston: Springer, 35-102.

411 https://doi.org/10.1007/978-1-4684-8094-8_2 
412 Boll PK, Leal-Zanchet AM. 2016. Preference for different prey allows the coexistence of several 413 land planarians in areas of the Atlantic Forest. Zoology 119:162-168.

414 doi:10.1016/j.zool.2016.04.002

415 Carbayo F, Álvarez-Presas M, Olivares CT, Marques FPL, Froehlich EM, Riutort M. 2013.

416 Molecular phylogeny of Geoplaninae (Platyhelminthes) challenges current classification:

417 proposal of taxonomic actions. Zoologica Scripta 42:508-528.

$418 \quad$ https://doi.org/10.1111/zsc. 12019

419 Castro RA, Leal-Zanchet AM. 2005. Composição de comunidades de planárias terrestres

420 (Platyhelminthes) em áreas de floresta estacional decidual e de campo na região central do

421 Rio Grande do Sul, Brasil. Acta Biologica Leopoldensia 27:147-150.

422 Cseh A, Carbayo F, Froehlich EM. 2017. Observations on food preference of Neotropical land 423 planarians (Platyhelminthes), with emphasis on Obama anthropophila, and their phylogenetic 424 diversification. Zoologia 34:1-8. doi:10.3897/zoologia.34.e12622

425 Froehlich CG. 1955a. On the biology of land planarians. Boletim da Faculdade de Filosofia, 426 Ciências e Letras da Universidade de São Paulo, Zoologia 20:263-272.

427 Froehlich CG. 1955b. Sobre a morfologia e taxonomia das Geoplanidae. Boletim da Faculdade 428 de Filosofia, Ciências e Letras da Universidade de São Paulo, Série Zoologia, 19:195-279.

429 Kamimura Y. 2006. Right-Handed penises of the earwig Labidura riparia (Insecta, Dermaptera, 430 Labiduridae): evolutionary relationships between structural and behavioral asymmetries. 431 Journal of Morphology 267:1381-1389. https://doi.org/10.1002/jmor.10484

432 Kawaguti S. 1932. On the physiology of land planarians. Memoirs of the Faculty of Science and 433 Agriculture, Taihoku Imperial University 7:15-55

434 Leal-Zanchet AM, Baptista VA. 2009. Planárias terrestres (Platyhelminthes, Tricladida) em 435 remanescentes de Floresta com Araucária. In: Fonseca CR, Souza AF, Leal-Zanchet AM, 
436

437

438

439

440

441

442

443

444

445

446

447

448

449

450

451

452

453

454

455

456

457

Dutra T, Backes A, Ganade G, Eds. Floresta com Araucária: Ecologia, Conservação e Desenvolvimento Sustentável. Ribeirão Preto: Holos, 199-207.

Leal-Zanchet AM, Carbayo F. 2000. Fauna de planárias terrestres (Platyhelminthes, Tricladida, Terricola) da Floresta Nacional de São Francisco de Paula, RS, Brasil: uma análise preliminar. Acta Biologica Leopoldensia 22:19-25.

Leal-Zanchet A, Marques A. 2018. Searching for shelter in a ferruginous cave? A new species of Pasipha (Platyhelminthes, Tricladida) from a plateau in the Brazilian savanna. Zookeys 776:13-25. doi: 10.3897/zookeys.776.26308

Negrete L, Colpo KD, Brusa F. 2014. Land Planarian Assemblages in Protected Areas of the Interior Atlantic Forest: Implications for Conservation. PLoS ONE 9:e90513. doi:10.1371/journal.pone.0090513

Ogren RE. 1995. Predation behaviour of land planarians. Hydrobiologia 305:105-111.

Ogren RE, Kawakatsu M. 1990. Index to the species of the family Geoplanidae (Turbellaria, Tricladida, Terricola). Part I: Geoplaninae. Bulletin of the Fuji Women's College, Ser. 2 28:79-166.

Oliveira PA, Pereira IM, Messias MCTB, Oliveira MLR, Pinheiro AC, Machado ELM, Oliveira JLA. 2018. Phytosociology of the herbaceous-subshrub layer of a rupestrian complex in Serra do Espinhaço, Brazil. Acta Botanica Brasilica 32:141-149. https://doi.org/10.1590/0102$33062017 \mathrm{abb} 0225$

Pellegrini T, Ferreira R. 2012. Metodologias diferenciadas aumentam a eficiência de inventários faunísticos em cavernas. Arquivos do Museu de História Natural e Jardim Botânico 21:111121. 
458 Prasniski MET, Leal-Zanchet AM. 2009. Predatory behaviour of the land flatworm

459 Notogynaphallia abundans (Platyhelminthes: Tricladida). Zoologia 26(4):606-612.

460 Rapini AA, Ribeiro PL, Lamberti S, Pirani JR. 2008. A flora dos campos rupestres quartzíticos

461 da Cadeia do Espinhaço. Megadiversidade 4:16-24.

462 Rocha BN, Galvani E. 2011. Microclima de ambientes cavernícolas: estudo de caso da Gruta da

463 Santa, Parque Estadual de Intervales, SP. Revista Brasileira de Climatologia 9:21-34.

$464 \quad$ http://dx.doi.org/10.5380/abclima.v9i0.27508

465 Rossi I, Amaral SV, Ribeiro GG, Cauduro GP, Fick I, Valiati VH, Leal-Zanchet AM. 2015. Two

466 new Geoplaninae species (Platyhelminthes: Continenticola) from Southern Brazil based on an

467 integrative taxonomic approach. Journal of Natural History 50:1-29.

$468 \quad$ https://doi.org/10.1080/00222933.2015.1084057

469 Sluys R. 1995. Platyhelminthes as paleogeographical indicators. Hydrobiologia 305:49-53.

470 Winsor L, Johns PM, Yeates GW. 1998. Introduction, and ecological and systematic

471 background, to the Terricola (Tricladida). Pedobiologia 42:389-404.

472 


\section{Figure 1}

Type-locality of Difroehlichia elenae sp. nov., a ferruginous cave located in Conceição do Mato Dentro, state of Minas Gerais, Brazil.

The asterisk indicates the cave location; the outline indicates areas impacted by mining exploitation. Modified from Leal-Zanchet \& Marques (2018). 


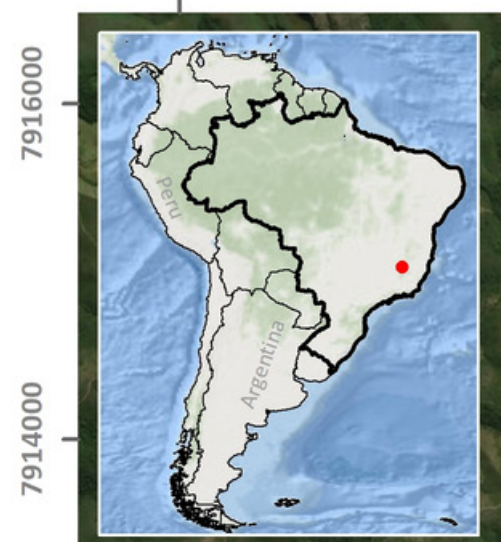

ঃั

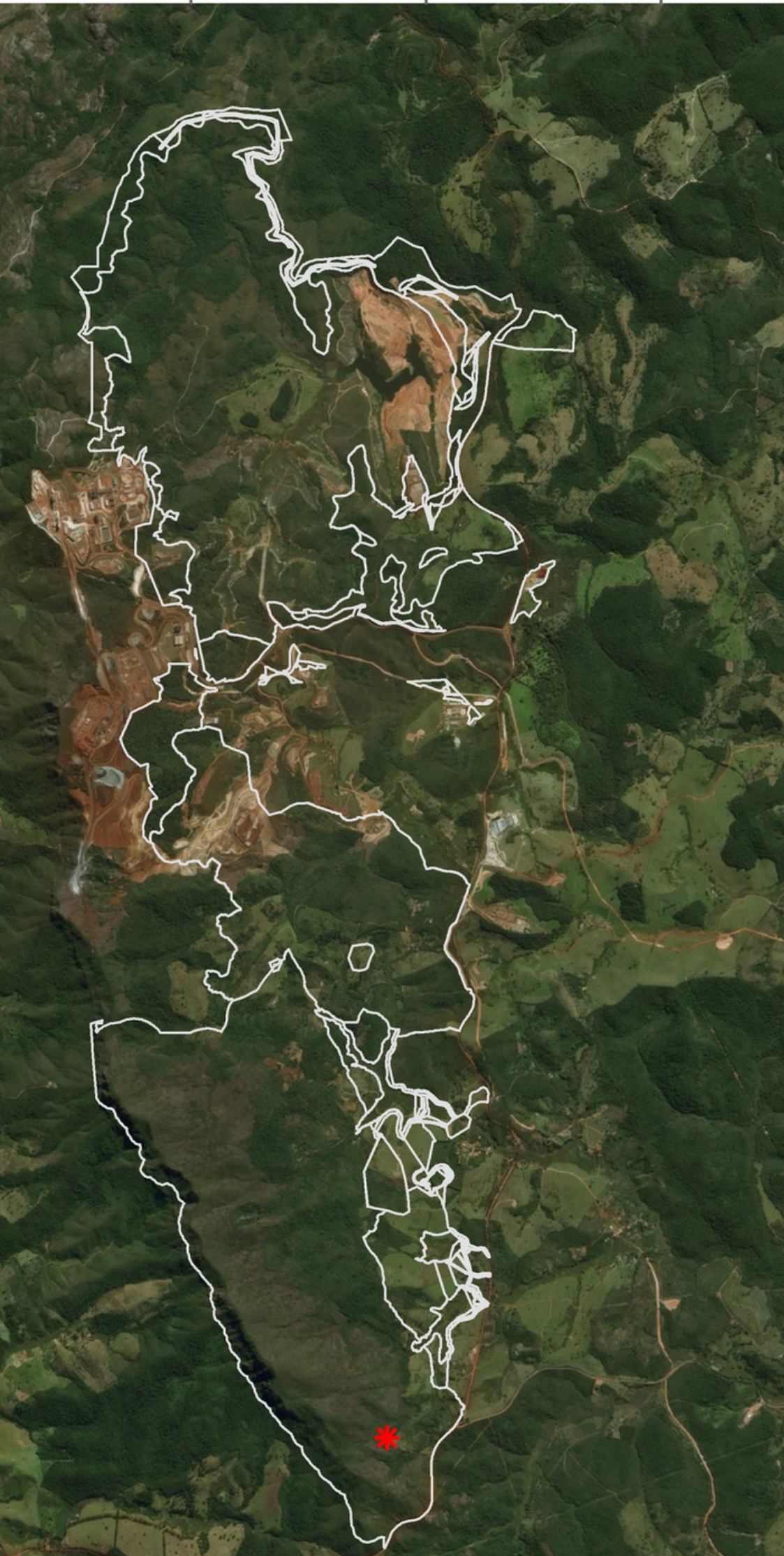




\section{Figure 2}

Difroehlichia elenae sp. nov., holotype.

(A) General dorsal view of preserved specimen. (B) Dorsal view of the anterior region of body. (C) Ventral view of the anterior region of body. The arrow indicates the anterior extremity.
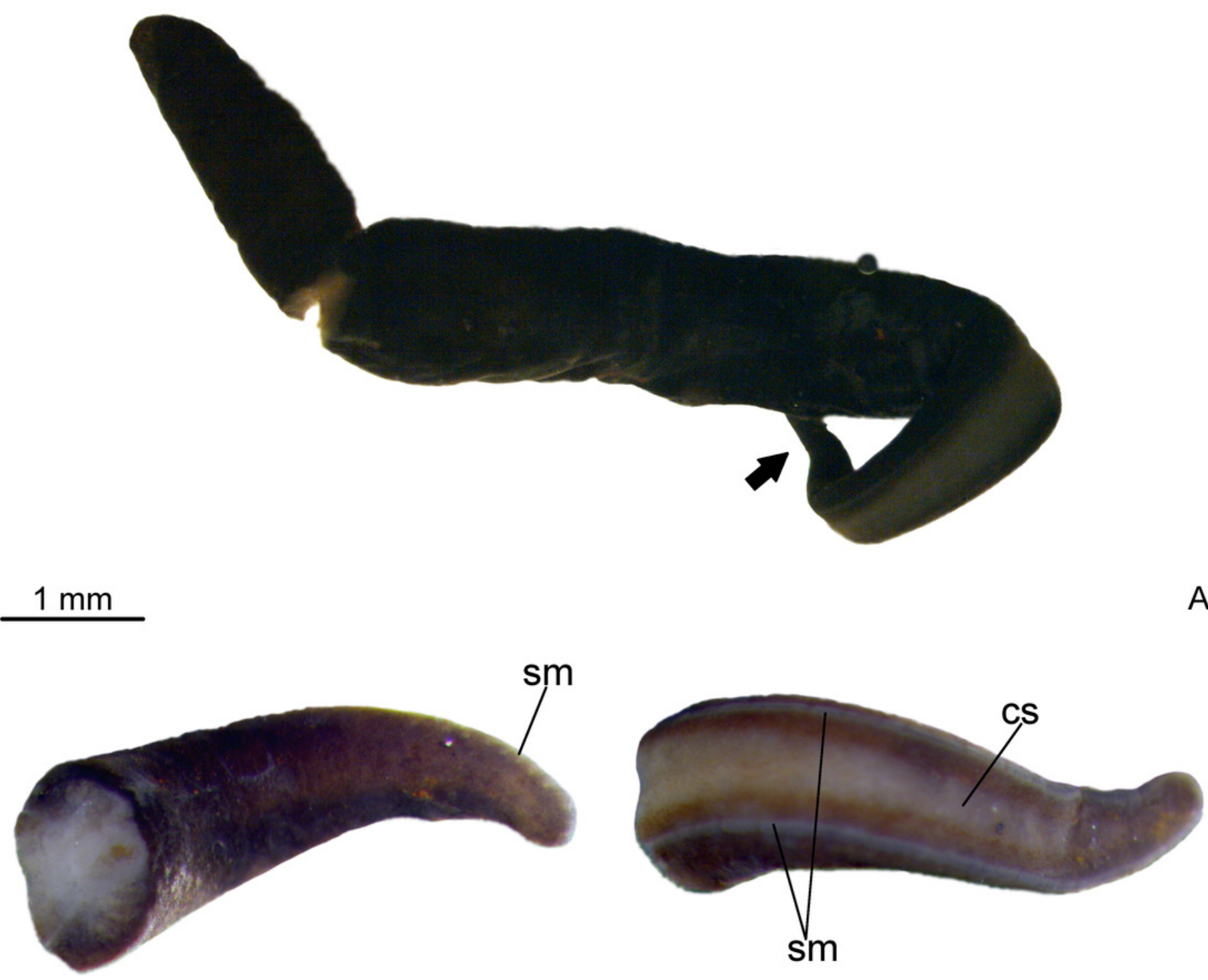

$1 \mathrm{~mm}$

B

$1 \mathrm{~mm}$

C 


\section{Figure 3}

Difroehlichia elenae sp. nov., holotype, transverse sections.

(A-C) Anterior region: general view (A) and details of the creeping sole (B) and body margins

(C). (D-F) Pre-pharyngeal region: general view (D) and details of the creeping sole (E) and body margins $(\mathrm{F})$. 

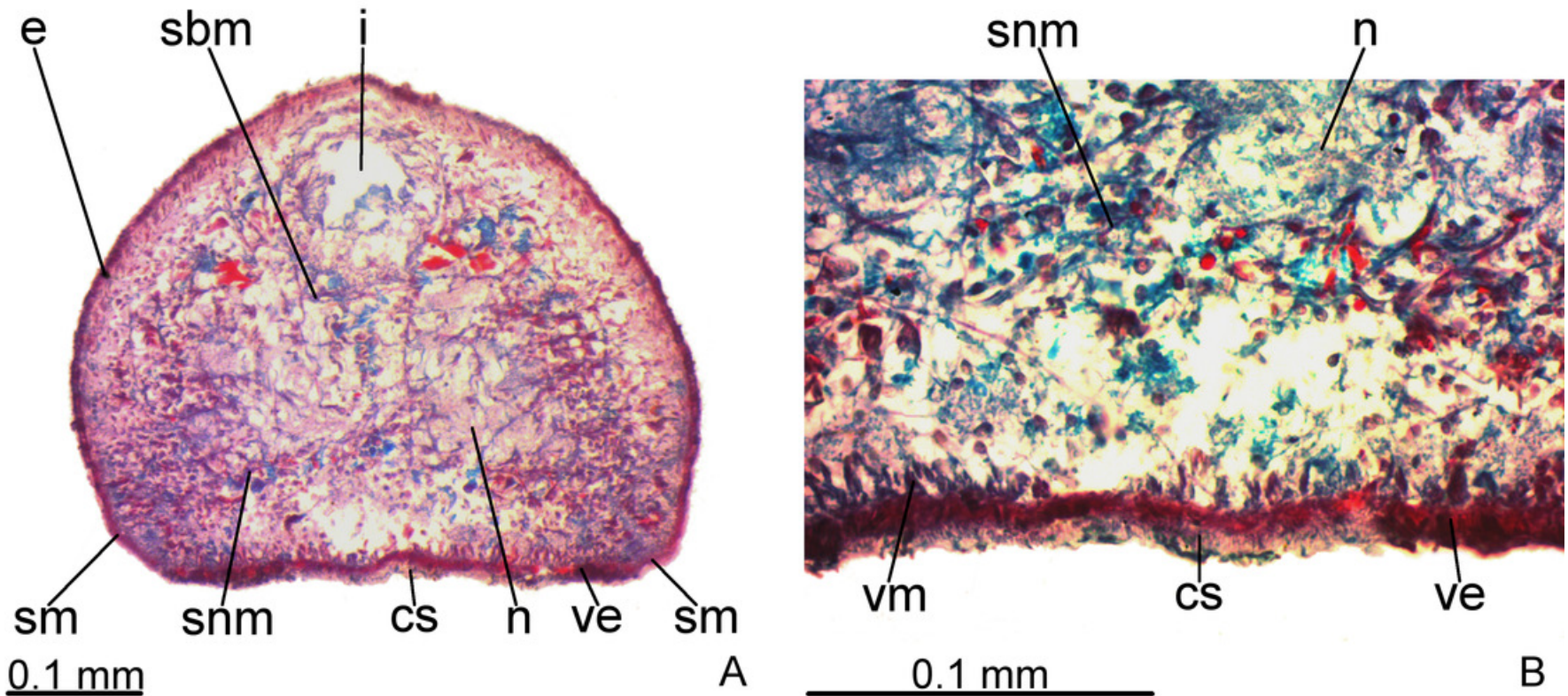

A
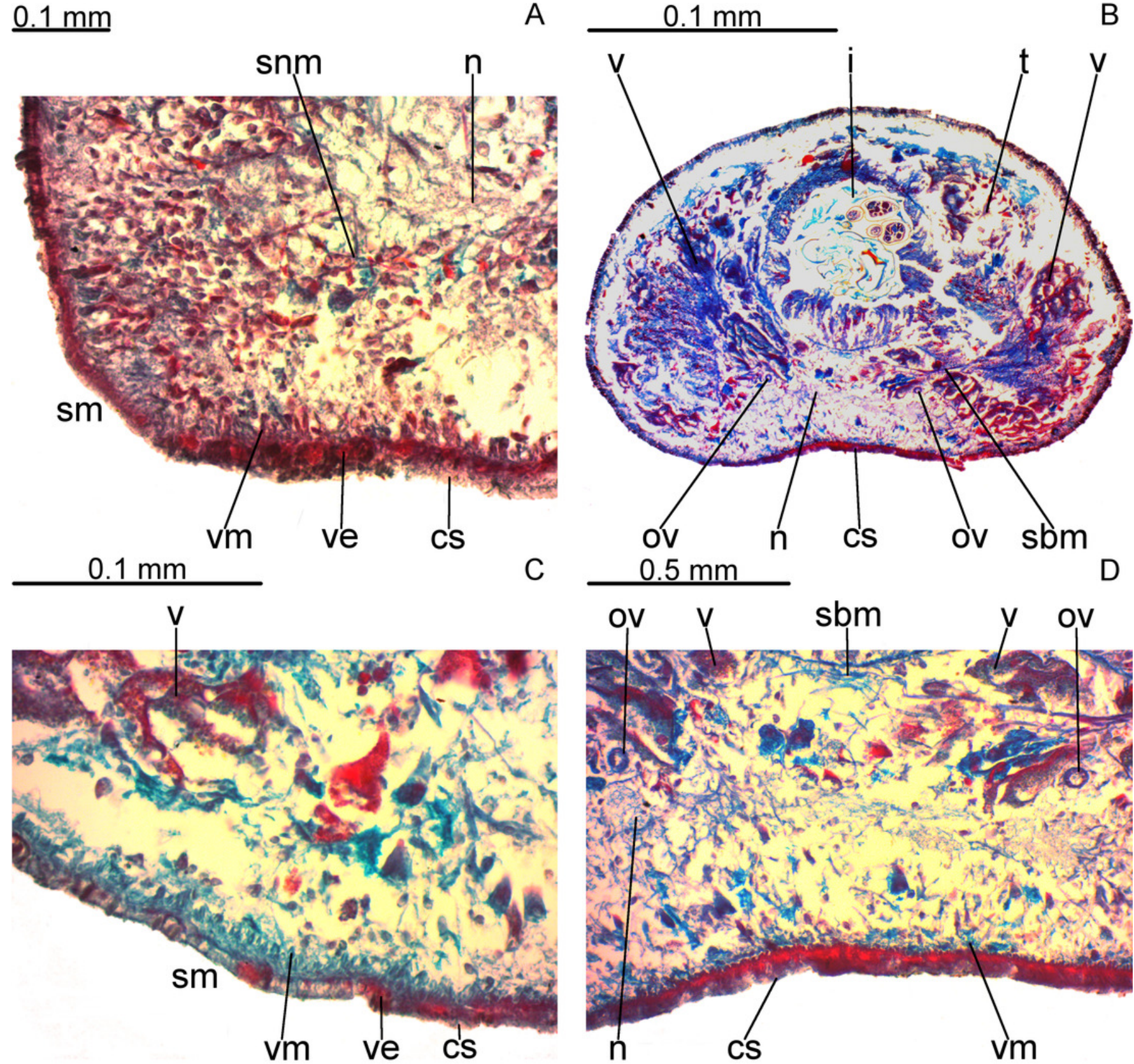
Figure 4

Difroehlichia elenae sp. nov., holotype, sagittal sections.

(A) Pharynx. (B) Ovary.
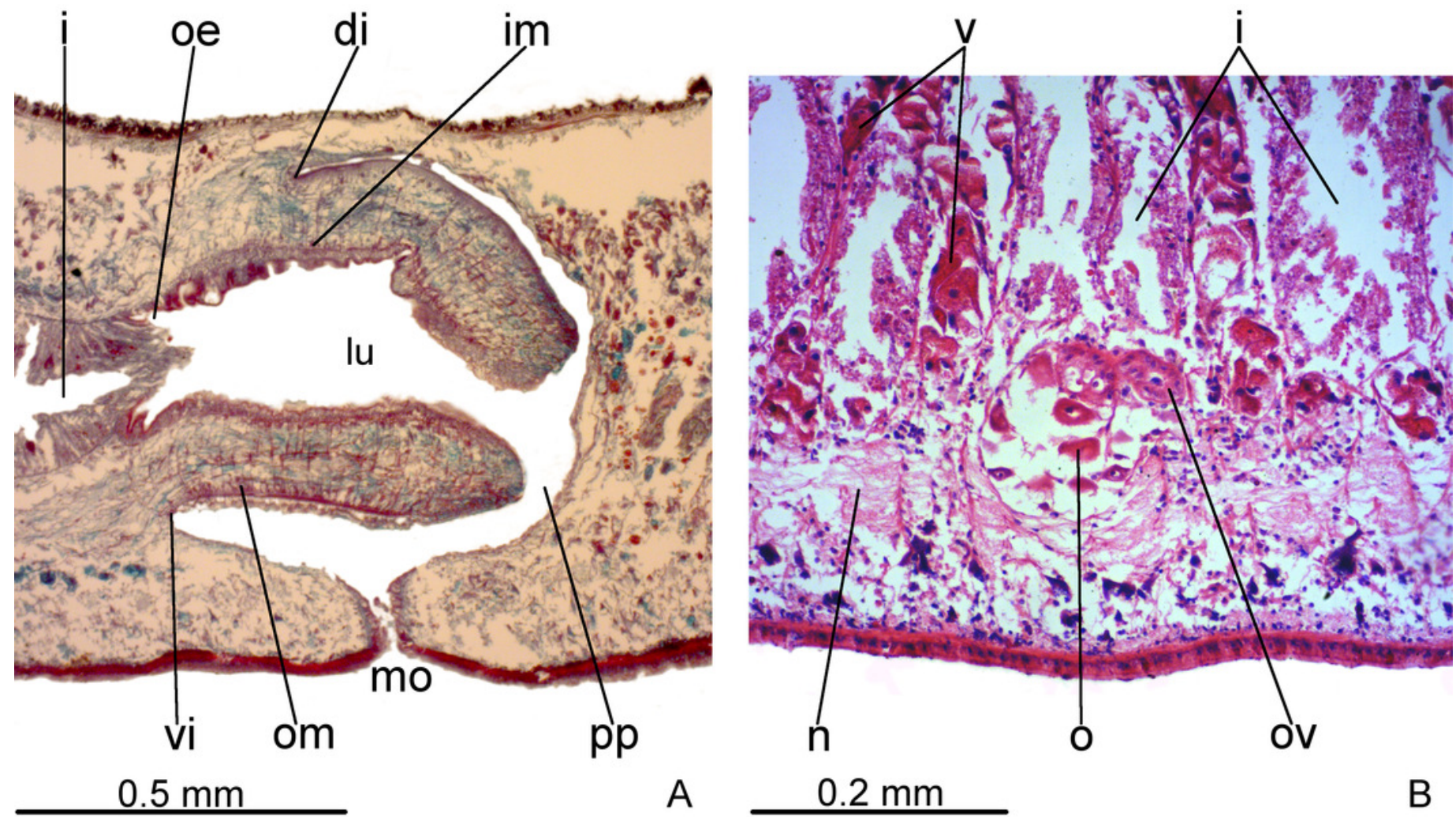
Figure 5

Difroehlichia elenae sp. nov., holotype. Sagittal composite reconstruction of copulatory apparatus.

The secondary male organ is shown in green.

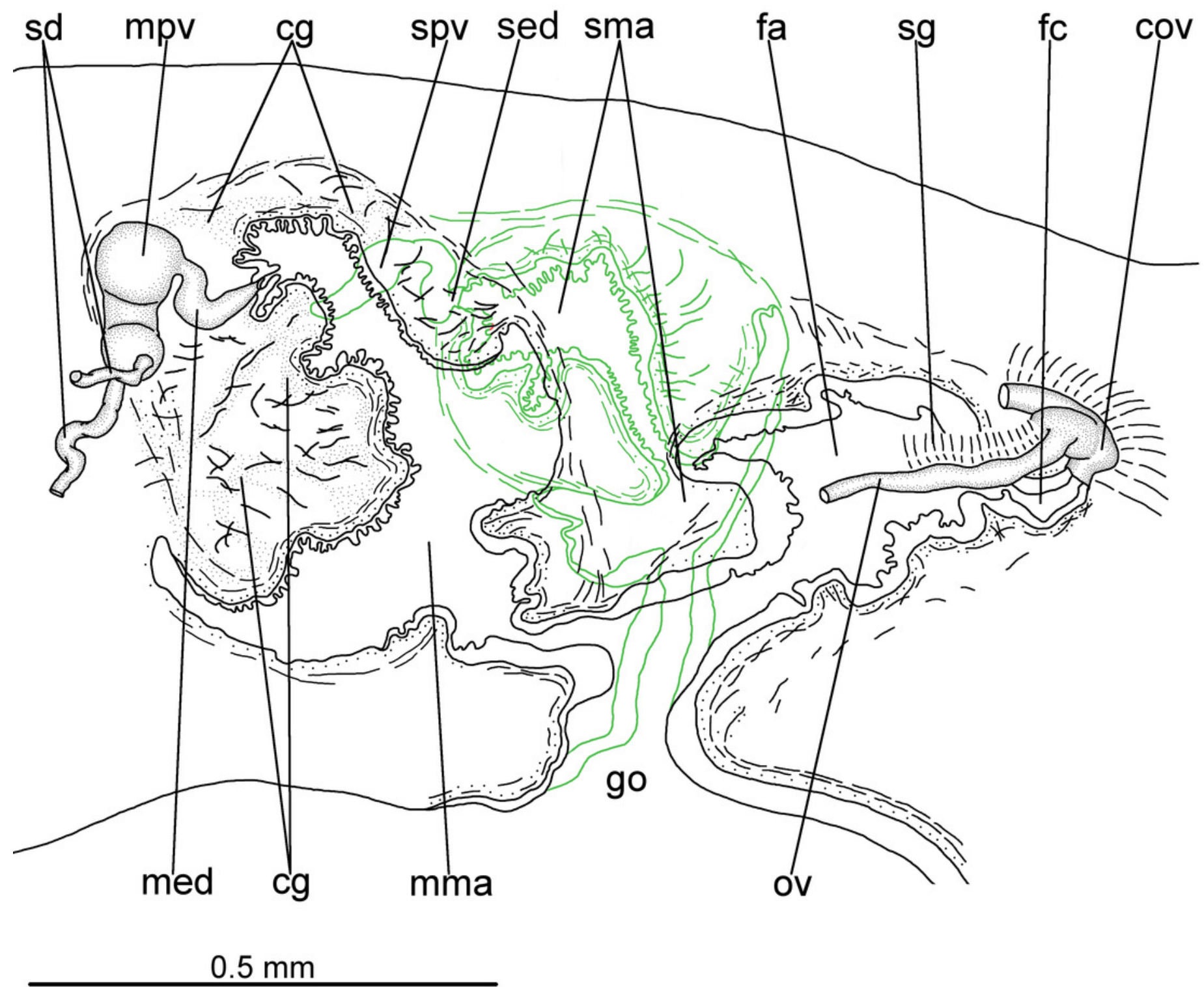




\section{Figure 6}

Difroehlichia elenae sp. nov., holotype, copulatory apparatus in sagittal sections.

(A) General view. (B) Detail of the prostatic vesicle with opening of a sperm duct. (C) Opening of ejaculatory duct into male atrium. (D) Primary and secondary male organs. (E) Secondary male organs. 

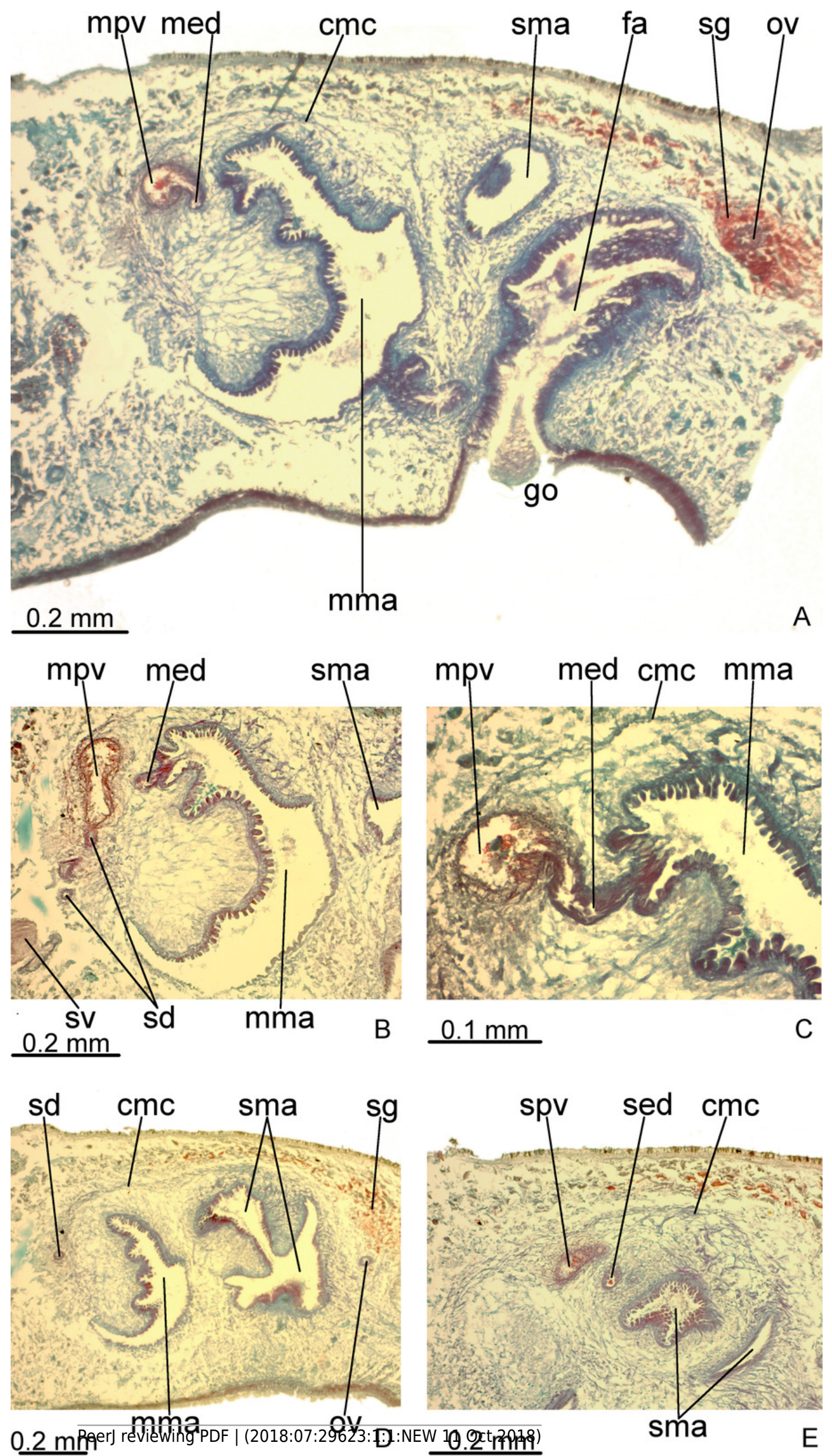
Figure 7

Difroehlichia elenae sp. nov., holotype, copulatory apparatus in sagittal sections.

(A) Female atrium communicating with common ovovitelline duct. (B) Detail of the lining epithelium of female atrium. Arrows indicate lacunae.

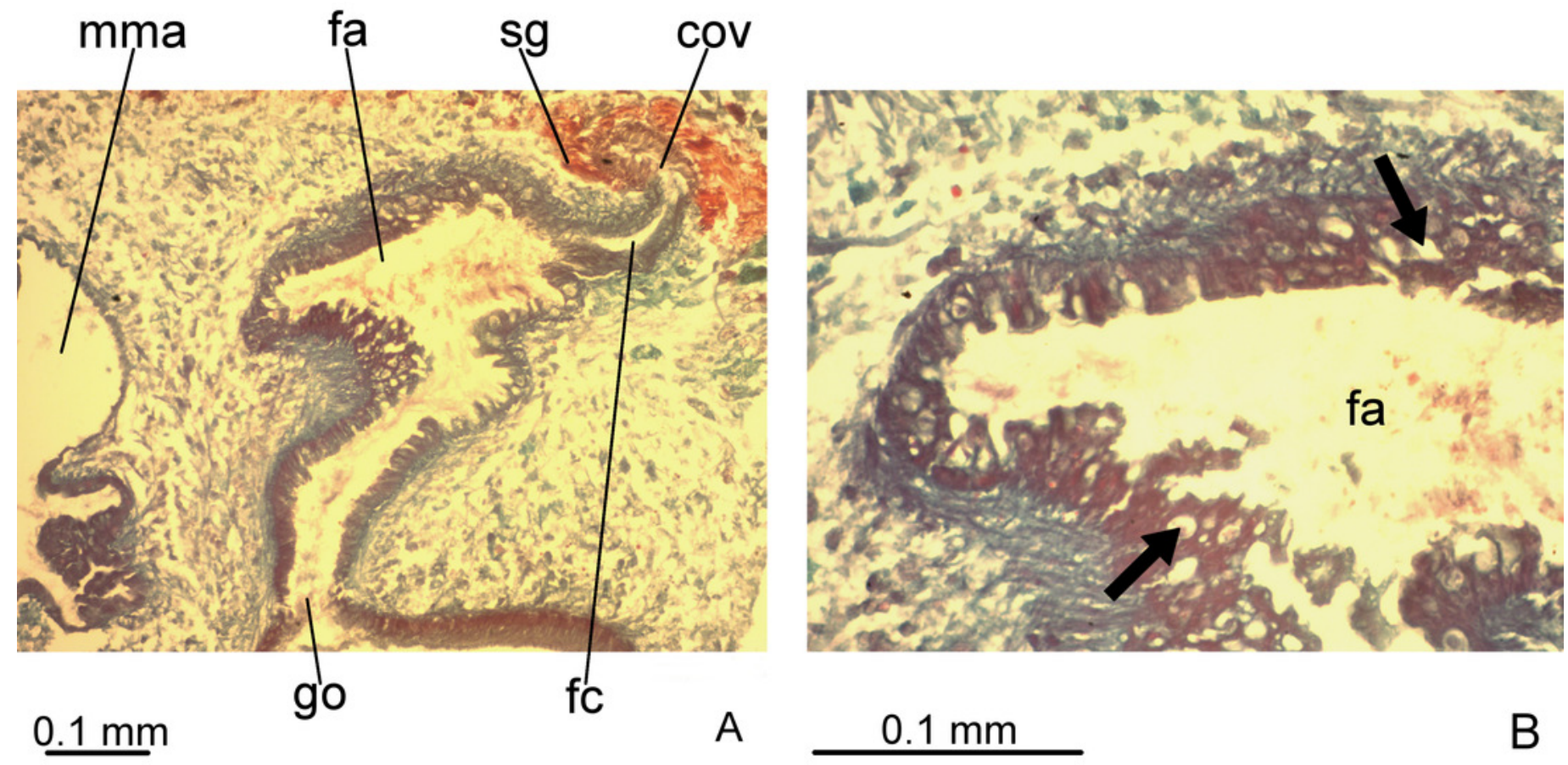




\section{Figure 8}

Type-locality of Difroehlichia elenae sp. nov.

(A) Entrance of the ferruginous cave that represents the type-locality, at the basis of a vertical slope in rocky outcrop in the Brazilian savanna. (B) Detail of the cave lithology, showing banded iron rocks. 


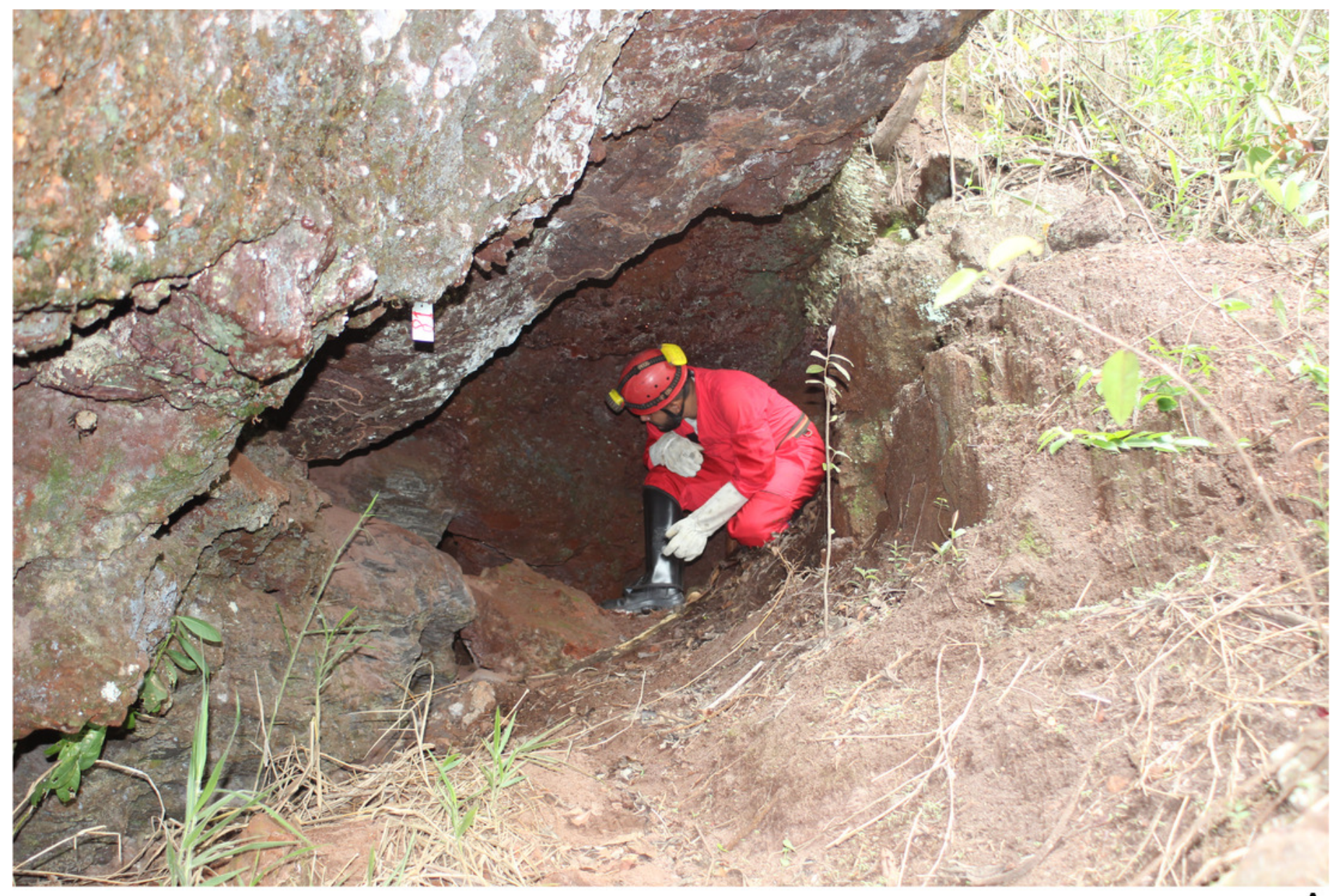

A

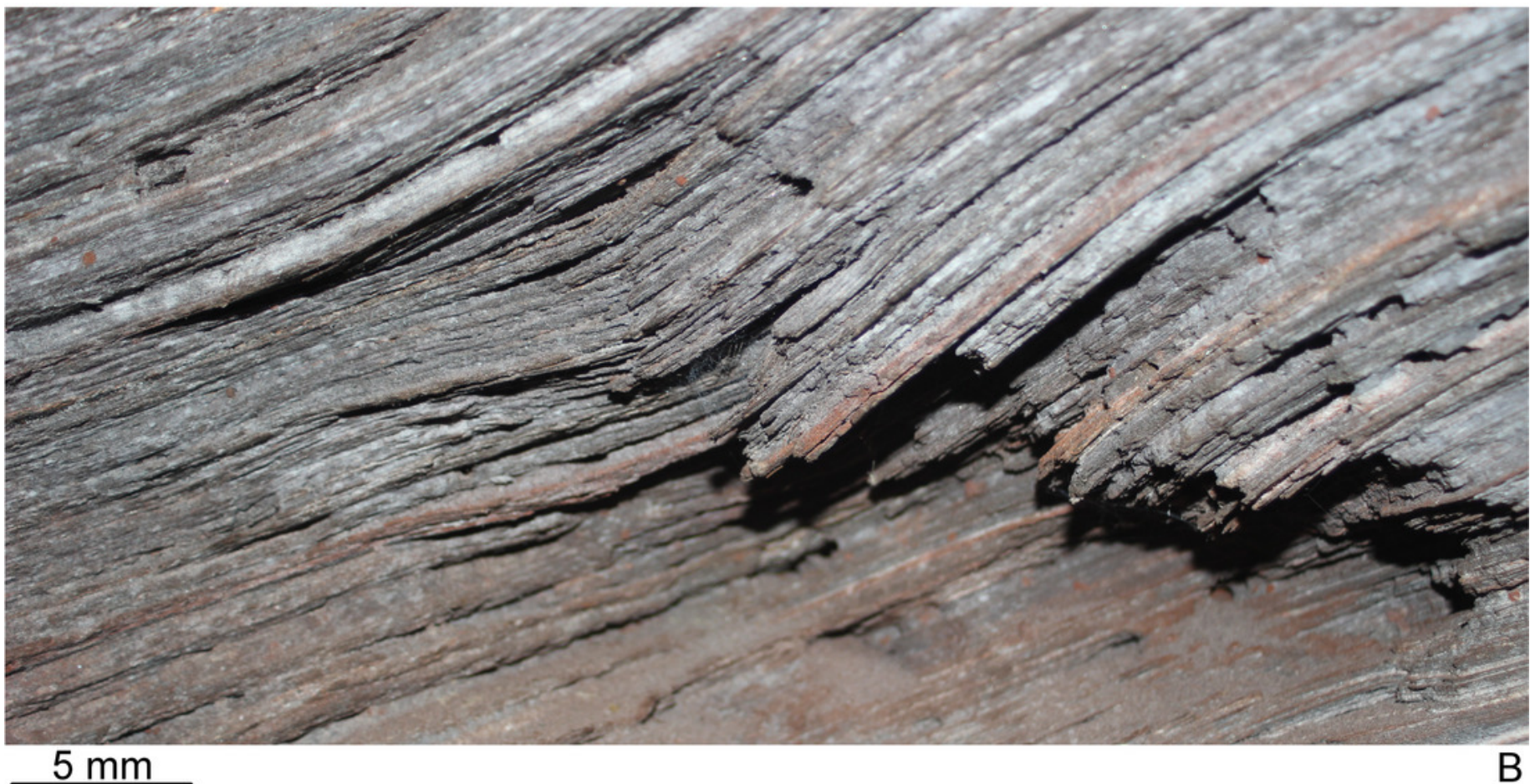

